\title{
Chronic hepatitis B infection in Canada
}

\author{
GY Minuk MD FRCPC, J Uhanova MD MSc
}

GY Minuk, J Uhanova. Chronic hepatitis B in Canada. Can J Infect Dis 2001;12(6):351-356.

Recent developments in the treatment and prevention of hepatitis B virus (HBV) infections warrant revisiting important epidemiological questions, such as how prevalent is chronic HBV infection in Canada, in which Canadian subpopulations are HBV prevalence rates the highest, in what percentage of infected individuals is the virus actively replicating, and how many infected Canadians are candidates for antiviral therapy? Currently available data suggest the overall prevalence of HBVinfected individuals in the general population is approximately $2 \%$, with $5 \%$ to $10 \%$ having serological evidence of previous $\mathrm{HBV}$ infection. In high risk groups, such as street-connected individuals, Aboriginals and immigrants from endemic areas, these rates of viral prevalence and serological evidence of previous HBV infection are approximately two to 10 and five to 10 times higher, respectively, than in the general population. Candidates for antiviral therapy range from less than $1 \%$ of infected Aboriginals to $15 \%$ to $30 \%$ of Asians with chronic HBV. From these data, it is clear that chronic HBV remains an important public health problem in this country. Hence, resources must be identified to enhance Canadians' awareness of HBV infection, maintain, if not expand, efforts to identify and implement safe and effective antiviral therapy for HBV-infected individuals, and continue programs for universal vaccination to prevent new HBV infections.

Key Words: Canada; Epidemiology; Hepatitis; Hepatitis B; Hepatitis B virus; Liver; Liver disease

\section{L'hépatite B chronique au Canada}

RÉSUMÉ : Compte tenu de récents progrès réalisés aux chapitres du traitement et de la prévention de l'hépatite $\mathrm{B}$, il semble justifié de revoir les grandes questions épidémiologiques, par exemple, quelle est la prévalence de l'hépatite B chronique au Canada, dans quelle sous-population du Canada les taux de prévalence du HBV sont-ils les plus élevés, dans quel pourcentage des sujets infectés le virus se multiplie-t-il activement et combien de Canadiens infectés sont des candidats au traitement antiviral? Selon les données actuellement disponibles, la prévalence globale de l'infection au HBV dans la population générale s'élèverait à environ $2 \%$, de 5 à $10 \%$ présentant des signes sérologiques d'infection au HBV. Dans les groupes à risque, par exemple chez les sans-abris, les Autochtones et certaines populations immigrantes provenant de régions endémiques du globe, ces taux de prévalence globale et de signes sérologiques d'infection au HBV sont de 2 à 10 et de 5 à 10 fois plus élevés respectivement que dans la population en général. Les pourcentages de candidats au traitement antiviral varient de moins de $1 \%$ chez les Autochtones infectés à 15 ou $30 \%$ chez les Asiatiques porteurs d'une infection chronique par le HBV. À partir de ces données, il est clair que le HBV reste un important problème de santé publique dans ce pays. Des ressources doivent donc être trouvées pour sensibiliser davantage les Canadiens au HBV, pour maintenir sinon élargir les efforts déployés pour découvrir et administrer un traitement antiviral sûr et efficace aux sujets infectés par le HBV et pour maintenir en place les programmes de vaccination universelle de façon à prévenir de nouvelles infections par le HBV.

Glaxo Wellcome/Bio Chem Pharma Hepatitis B Care Unit, Liver Diseases Unit, Departments of Medicine and Pharmacology, University of Manitoba, Winnipeg, Manitoba

Correspondence and reprints: Dr GY Minuk, Liver Diseases Unit, John Buhler Research Centre, 803F-715 McDermot Avenue, Winnipeg,

Manitoba R3E 3P4. Telephone 204-789-3204, fax 204-789-3971, e-mail gminuk@cc.umanitoba.ca

Received for publicationNovember 30, 2000. Accepted May 7, 2001 
$\mathrm{H}^{2}$ epatitis B virus (HBV) infections are the ninth most common cause of death by disease in the world today (1). The majority of deaths due to HBV infection occur as a result of complications of cirrhosis and/or hepatocellular carcinoma (2). Recently, new developments in the treatment of chronic $\mathrm{HBV}$ infections (defined as serological evidence of HBV infection beyond six months duration) provide promise that the course of the disease may be favourably altered $(3,4)$. Moreover, effective immunoprophylaxis raises the distinct possibility that HBV may eventually be eradicated from the world's population (5). In light of these encouraging therapeutic and preventive developments, it is timely to review the prevalence of chronic HBV infections in the general population of Canada and in certain high risk Canadian populations.

\section{HBV IN THE GENERAL POPULATION OF CANADA}

Numerous studies have attempted to document the prevalence of HBV carriers (for the purpose of this review 'carriers' are defined as individuals with a positive hepatitis B surface antigen (HBsAg) result for more than six months, regardless of viral or disease activity) in the general population of Canada (6-10). The results are prevalence figures that vary from $0.1 \%$ in pregnant women attending prenatal clinics in the Maritimes to $2.1 \%$ in unselected patients admitted to urban hospital centres $(11,12)$. Volunteer selection bias notwithstanding, perhaps the results that most accurately reflect the true HBV carrier rate in the general population are those obtained by the Canadian Red Cross in the late 1970s, before the organization began discouraging donations from individuals at high risk for HIV infections, when $0.3 \%$ of firsttime blood donors were found to be HBsAg-positive (13). When the prevalence of HBsAg positivity in the high risk populations of Canada, such as Asians, Aboriginals, etc and the contributions that these groups make to the total population of the country are factored in, an estimated $2 \%$ of the Canadian population are HBsAg carriers, with approximately $5 \%$ to $10 \%$ having serological markers of previous HBV exposure (anti-hepatitis core antigen $[\mathrm{HBc}]$-positive).

Relatively few studies have documented the percentage of HBV carriers in Canada who have serological evidence of active (hepatitis B early antigen (HBeAg)-positive or HBeAgnegative with a positive HBV-DNA test by a non-polymerase chain reaction [PCR] assay) viral replication. One exception is a study by Richer et al $(14,15)$, wherein approximately $5 \%$ of 700 Red Cross blood donors found to be HBsAg-positive were HBeAg-positive and in excess of $80 \%$ were anti-HBe-positive. On the other hand, in a smaller study by Kim et al (16), almost $60 \%$ of HBsAg-positive nonimmigrants were HBeAgpositive, while $31 \%$ were anti-HBe-positive. Of note, the Richer results $(14,15)$ more closely resemble data from the United States, where $15 \%$ of the HBsAg-positive carrier population is HBeAg-positive and $75 \%$ is anti-HBe-positive (17).

Relevant to the issue of antiviral therapy is the proportion of patients with active viral replication who have biochemical evidence of hepatic inflammation. In a study by Villeneuve et al (18), of $20 \mathrm{HBeAg}$-positive patients referred to their terti- ary care centre, 14 (70\%) had elevated liver enzymes, a figure similar to the $77 \%$ reported by Kim et al (16) in 43 HBeAg-positive carriers referred to their institution.

Hepatitis D virus (HDV or delta agent) only infects individuals who are coinfected or have underlying chronic HBV infections. To date, three studies have reported the prevalence of HDV infection (anti-HDV-positive) in predominantly non-Aboriginal, non-Asian Canadian populations. In a study by Cheng et al (19) consisting of $245 \mathrm{HBsAg}$-positive western Canadians, only four (1.5\%) were anti-HDV positive. A slightly higher figure (4\%) was described by Hannan et al (20) in 123 HBsAg-positive carriers residing in Manitoba. The lowest HDV infection rates were reported by Villeneuve et al (18), where only one of $218(0.5 \%)$ HBsAg-positive carriers was found to be anti-HDV-positive.

HBV and hepatitis $\mathrm{C}$ virus (HCV) coinfections were described in less than $1 \%$ of 218 HBsAg-positive carriers studied by Villeneuve et al (18), using a second generation ELISA assay for anti-HCV. Presumably, higher rates are present in high risk Canadian populations, but this has yet to be reported.

It is difficult to ascertain the histological extent of disease in HBsAg-positive Canadians because the data are largely limited to patients who have been referred to secondary or tertiary care centres, and among those, only patients with more active disease tend to be biopsied. Nonetheless, in studies where such data are available, active histological disease was identified in $15 \%$ to $50 \%$ and cirrhosis in under $20 \%$ of biopsied cases $(18,19,21)$.

There has been only one study reported to date documenting the incidence of hepatocellular carcinoma arising in HBsAg-positive Canadians who were not born in areas of the world where HBV is endemic (18). In the study, 317 subjects were followed for more than 16 years (5135 carrier years of follow-up), and no cases of hepatocellular carcinoma were identified. Based on incidence rates reported from general population studies in Alaska and Southeast Asia, 17 cases would have been predicted $(22,23)$. Thus, hepatocellular carcinoma does not appear to be as common in HBsAg-positive carriers born and residing in Canada compared with immigrants from or individuals residing in moderate and high HBV prevalence areas of the world. The reason for this finding likely reflects differences in the age of infection, extent of exposure to putative tumour-promoting agents within certain diets and duration of follow-up (24). Despite the low incidence of hepatocellular carcinoma among Canadians with HBV, approximately $30 \%$ of Canadians undergoing liver transplantation for hepatocellular carcinoma are HBsAg positive (25). However, the demographic features of this population (eg, country of origin, ethnic background, etc) are unclear.

Annual spontaneous seroconversion rates from active, replicative disease (HBeAg-positive) to inactive, nonreplicative states (loss of HBeAg and appearance of anti-HBe) have been reported by Kim et al (16) and Villeneuve et al (18) in 7\% and $17 \%$ of their carrier populations, respectively. Complete resolution of infection (seroconversion from HBsAg to anti- 
HBs positive) occurs in approximately $0.5 \%$ to $1 \%$ of carriers per year (18). These seroconversion rates are similar to those reported elsewhere in the world (26).

In summary, with respect to the general population, approximately $2 \%$ of the population of Canada is likely to be HBsAg positive and $5 \%$ to $10 \%$ have serological markers of previous HBV exposure (Table 1). Of the HBsAg-positive carriers, approximately $40 \%$ will be $\mathrm{HBeAg}$-positive and $35 \%$ of these individuals will have elevated liver enzymes. Although not indicated in Table 1, approximately $15 \%$ of HBeAg-positive patients are expected to spontaneously seroconvert to anti-HBe positivity and $0.5 \%$ of HBsAg-positive carriers spontaneously seroconvert to anti-HBs positivity annually. HDV coinfections occur in less than $5 \%$ of HBsAg-positive carriers, and an even smaller percent are coinfected with HCV. It is likely that cirrhosis is present in $10 \%$ to $15 \%$ of HBsAg-positive carriers, and the risk of hepatocellular carcinoma in Canadian carriers is low according to one study (18).

\section{HIGH RISK POPULATIONS}

Non-Aboriginal/non-Asian high risk groups: Sexual promiscuity and intravenous drug use are the two most common routes of HBV transmission in low endemic areas (26). In Canada, Yuan and Robinson (27) identified $0.9 \%$ of homosexual and bisexual individuals as being HBsAg-positive and $18 \%$ as having serological evidence of previous HBV exposure. Increased prevalences of HBV exposure have also been documented in individuals attending sexually transmitted disease clinics in this country $(28,29)$. The highest prevalence figures for HBV exposure have been described in urban street youths, where nine of 43 prostitutes (21\%) were found to be anti-HBc and/or anti-HBs seropositive (30). A somewhat lower figure (9.2\%) was reported by Roy et al (31) in their study of 437 street youths in Montreal. The same study identified age older than 18 years, history of injection drug use and a sexual partner with unspecified hepatitis as independent factors associated with HBV in this population. Finally, a $2.5 \%$ HBsAg carrier rate and 5\% prevalence of exposure was documented in institutionalized, mentally handicapped individuals (32).

Aboriginal population: As of 1996, the total registered Aboriginal population of Canada was 799,010 people (33). Together with the nonregistered population, it has been estimated that in excess of 1,000,000 Inuit and First Nations peoples reside in Canada. The largest percent $(23 \%)$ are in the province of Ontario.

The first study documenting the prevalence of HBV infection in an Aboriginal population was performed by Minuk et al (34) in 1980, when 720 of 817 inhabitants (88\%) of the community of Baker Lake, Northwest Territories were studied. In excess of $90 \%$ of this study population were Inuit, with an equal representation of males and females. All ages from three months to 86 years were included. The results of serological testing revealed that $4 \%$ were $\mathrm{HBsAg}$ positive and $27 \%$ had evidence of previous HBV exposure. Males were twice as likely to be HBsAg-positive than females. None of
TABLE 1

Hepatitis B virus in Canada

\begin{tabular}{|c|c|c|c|c|}
\hline & $\begin{array}{l}\text { Non-Aboriginal, } \\
\text { non-Asian* }\end{array}$ & Aboriginal* & Asian* & Overall* \\
\hline $\mathrm{HBsAg}$ & 0.5 & $3-5$ & 15 & 2 \\
\hline Anti-HBc & 5 & 25 & 60 & $5-10$ \\
\hline $\begin{array}{l}\mathrm{HBeAg} \\
\text { (\% of HBsAg carriers) }\end{array}$ & $5-15$ & $0-10$ & 50 & 40 \\
\hline $\begin{array}{l}\mathrm{HBeAg}^{+} \text {and } \mathrm{ALT} \uparrow \\
\text { (\% of } \mathrm{HBeAg} \text { carriers) }\end{array}$ & 50 & $?$ & 30 & 35 \\
\hline Precore & $?$ & 80 & $?$ & $?$ \\
\hline
\end{tabular}

the 49 Caucasians in this community were HBsAg positive, and serological evidence of previous HBV exposure was present in only $5 \%$. Serotyping of the HBV revealed serotype adw in all cases.

The age at which Inuit in the community became infected is unclear. HBsAg persistence rates reflect the age of $\mathrm{HBV}$ exposure and are calculated by dividing the number of HBsAg-positive individuals by the number of individuals with any positive HBV marker. In this community, the persistence rate was $15 \%$, suggesting these individuals tended to be infected at birth or during early childhood. However, agespecific prevalence rates revealed no carriers under the age of 20 years and relatively low rates of HBV exposure until early adulthood and beyond. Also in keeping with limited neonatal and childhood exposure were the results of HBeAg and antiHBe testing, wherein high HBeAg-positive rates are predicted in populations where infection occurs early in life. In the 36 HBsAg-positive carriers identified in Baker Lake, none were HBeAg positive and 34 were anti-HBe positive (35).

In addition to the unusual serological pattern, biochemical evidence of active liver disease was surprisingly rare. Indeed, no HBV carrier had elevated liver enzymes or abnormal liver function tests. Alpha-fetoprotein levels, which are elevated in $60 \%$ to $80 \%$ of patients with hepatocellular carcinoma, were within the normal range in all cases. Recently, 38 HBsAg-positive carriers from the region were further studied for evidence of viral mutations (36). A large percentage (80\%) were positive for the precore mutation, the highest reported prevalence to date.

Subsequent studies by Larke et al (36) in the Northwest Territories, Baikie et al (37) in Northern Labrador and Minuk et al (38) in an additional Inuit community adjacent to Baker Lake support the results of the initial study. Specifically, in the Larke study, of 14,198 residents of the Yukon and Northwest Territories, $3 \%$ were HBsAg-positive and $21 \%$ had serological evidence of previous HBV exposure. Rates of HBsAg positivity and serological evidence of previous HBV exposure in the Inuit ( $4 \%$ and $25 \%$, respectively) were similar to those in the Dene population ( $3 \%$ and $20 \%$, respectively) 
and higher than in Caucasians residing in the region $(0.3 \%$ and $8.5 \%$, respectively). Of note, Larke and colleagues (36) found a higher prevalence of HBeAg positivity $(8.8 \%)$ than was the case in the Minuk studies (0\%). In the Baikie study (37)of 2156 inhabitants of Northern Labrador, 3.2\% were HBsAg positive and $14.7 \%$ had evidence of previous $\mathrm{HBV}$ exposure. Once again, the HBsAg carrier and HBV exposure rates were significantly higher in the Inuit $(6.9 \%$ and $26.4 \%$, respectively) than in Caucasians ( $0 \%$ and $2.5 \%$, respectively). As in the Minuk studies (38), Baikie and colleagues did not find HBeAg positivity in their HBsAg-positive carriers, and described a low prevalence of HBV exposure (4\%) in individuals under the age of 20 years.

In a more high risk Aboriginal population, 1165 Native persons attending First Nations alcohol and drug treatment centres in British Columbia, Martin and Mathias (39) reported a relatively low HBsAg-positive rate $(0.3 \%)$ but increased past infection rate $(11.3 \%)$ compared with the remainder of the province $(0.5 \%$ and $5 \%$, respectively). This study is ongoing.

To date, serological evidence of HDV infection has not been detected in Aboriginals infected with HBV (40). HCV coinfection is also rare, at least in the Inuit population (41), but appears to be more common in urban Aboriginals belonging to high risk groups ( $8 \%$ with serological evidence of both HBV and HCV infections) (unpublished data). In the most extensive study reported to date, hepatocellular carcinoma was less common in the Canadian Inuit than in Eskimos residing in Alaska and Greenland (42).

Asian population: Statistics Canada has reported the Asian population in Canada to be slightly in excess of $3,000,000$ individuals, with two-thirds of those residing in the provinces of Ontario and British Columbia (33).

The largest seroepidemological survey of HBV infection in Canada's Asian population was carried out by Chaudhary et al (43) in 1981, wherein 14,347 first-generation immigrants to Canada were tested for serological evidence of HBV infection. The results revealed that $11.6 \%$ were HBsAg positive and $48 \%$ had serological evidence of previous HBV exposure. As reported elsewhere, carrier rates were higher in men (14\%) than in women (9\%), despite a similar rate of HBV exposure ( $51 \%$ and $47 \%$, respectively). Of interest, HBeAg positivity was clearly more common than was described in the general and Aboriginal carrier populations, in that $55 \%$ of Asian HBsAg carriers were HBeAg-positive and 39\% anti-HBe-positive. Subtyping of the HBsAg was different from the Inuit results, with the largest percentage of Asians (42\%) being serotype ayw, 35\% adr and $23 \%$ adw. Follow-up in this population revealed that within five years, $22 \%$ lost HBsAg, and evidence of HBV infection appeared in $18 \%$ of those who had been previously seronegative (44).

Further characterization of HBV infections in the Asian population was carried out by Wong and Minuk (45) in 1994, when 140 Chinese and Vietnamese HBsAg-positive carriers residing in Winnipeg were described. In that study, the majority $(61 \%)$ were male, with a mean age of 33.5 years. As described by Chaudhary et al (43), approximately $50 \%$ were
HBeAg positive. When tested for biochemical evidence of liver disease, $36 \%$ of HBeAg-positive patients had elevated serum alanine aminotransferase values beyond 1.5 times the upper limit of normal. In this study, findings in Chinese and Vietnamese immigrants were essentially similar.

The only prospective study of hepatocellular carcinoma developing in Asian immigrants to Canada reported to date was that by Sherman et al (46) in 1995. Here, $1069 \mathrm{HBsAg}$ positive carriers, with a mean age of 39 years, were followed for 2340 person years. The prevalence of hepatocellular carcinoma at the outset of the study was $281 / 100,000$, and the subsequent incidence rate was $470 / 100,000$, in keeping with the rates reported in areas of the world where HBV is endemic $(22,23,26)$.

\section{THERAPEUTIC IMPLICATIONS}

The indications for treating chronic HBV infections are serological evidence of active viral replication (HBeAg positive or positive HBV-DNA testing with non-PCR based assays, the latter having sensitivities of 0.7 to $1 \times 10^{6}$ copies $/ \mathrm{mL}$ ), and biochemical (alanine aminotransferase levels in excess of 1.5 times the upper limit of normal) or histological (grade II to IV inflammatory infiltrate) evidence of hepatic inflammation (47). Contraindications are relatively numerous for interferon therapy compared with nucleoside analogue-based regimens, such as lamivudine. Response rates are approximately similar (30\% to $40 \%$ of patients convert from active to inactive states of viral replication). Extensive reviews of the treatment of HBV infections have been published elsewhere (48-50).

In terms of treatment in Canada, according to the above epidemiological data, 65,000 to 85,000 Canadians would be candidates for antiviral therapy if no contraindications to treatment existed. Among these candidates, Asian immigrants would contribute the largest numbers $(67,500)$. Whether Canadian Aboriginals require therapy will depend on the results of natural history studies of the precore mutant variant of HBV and whether the Inuit and Dene data from the North can be extrapolated to other Aboriginal groups. The paucity of data regarding the numbers of nonAboriginal, non-Asian high risk groups (largely injection drug users and street-connected individuals) with chronic HBV precludes an estimate of what contribution this group will make to the total treatment population. Moreover, until compliance with therapy and abstinence from high risk activities improve in this population, those numbers remain of academic interest.

\section{SUMMARY}

In comparison with nonhigh risk groups, the HBsAg-positive carrier rate is two to five times higher in non-Aboriginal, non-Asian high risk groups, such as street-connected individuals, 10 to 20 times higher in the Aboriginal and 30 times higher in the Asian populations of Canada. Serological evidence of HBV exposure is two times more common in the non-Aboriginal, non-Asian high risk groups, five times more common in the Aboriginal and 10 times more common in the 
Asian populations than in the general population. HBeAg positivity in non-Aboriginal, non-Asian high risk carriers is unknown. It is uncommon in the Aboriginal but common $(50 \%)$ in the Asian carrier population. The finding of low rates of HBeAg positivity in the Aboriginal population may relate to a high prevalence of the precore mutant form of HBV infection in these individuals.

Relative to the issue of treatment, of the HBeAg-and/or HBV-DNA-positive carriers, few Aboriginals but $30 \%$ of Asians have elevated liver enzymes. Presumably, the lower figure in the Asian population (compared with the $65 \%$ to $75 \%$ figure among carriers in the general population) reflects a state of immune tolerance related to neonatal acquisition of the virus. HDV and HCV coinfections appear to be uncommon in nonhigh risk Aboriginal and Asian populations. With the exception of the Asian population, hepatocellular carcinoma also appears to be uncommon in these groups.

\section{CONCLUSION}

The above data suggest that Canada should continue to be considered a low prevalence country for chronic HBV infection. However, in certain subpopulations, particularly street-connected individuals, and the Aboriginal and Asian populations, rates of HBsAg positivity and HBV exposure are similar to or exceed those reported in high prevalence regions of the world. Thus, it is important that opportunities for further education about and, treatment and prevention of HBV be identified and implemented to help limit the spread and improve the outcome of HBV infection in the Canadian population.

ACKNOWLEDGEMENTS: The authors thank Ms S Zdanuk for her prompt and accurate typing of the manuscript.

\section{REFERENCES}

1. Maynard JE. Hepatitis B: global importance and need for control. Vaccine 1990;8(Suppl):518-20.

2. Sakuma K, Saitoh N, Kasai M, et al. Relative risks of death due to liver disease among Japanese male adults having various statuses for hepatitis B s and e antigen/antibody in serum: a prospective study. Hepatology 1988;8:1642-6.

3. Niederau C, Heintges T, Lange S, et al. Long-term follow-up of HBeAg-positive patients treated with interferon alpha for chronic hepatitis B. N Engl J Med 1996;334:1422-27.

4. Lai C-L, Chien R-N, Leung N, et al for the Asia Hepatitis Lamivudine Study Group. A one-year trial of lamivudine for chronic hepatitis B. N Engl J Med 1998;339:61-8.

5. Margolis HS, Alter MJ, Hadler SC. Hepatitis B: Evolving epidemiology and implications for control. Semin Liver Dis 1991;11:84-92.

6. Glasgow KW, Schabas R, Williams CD, Wallace E, Nalezyty LA. A population-based hepatitis B seroprevalence and risk factor study in a northern Ontario town. Can J Public Health 1997;88:87-90.

7. Simor AE, Gordon M, Bishai RF. Prevalence of hepatitis B surface antigen, hepatitis B antibody, and HIV-1 antibody among residents of a long-term care facility. J Am Geriatr Soc 1992;40:218-20.

8. Buchner BK, Duravetz JS, Moore BP. Prevalence of HBsAg and HBsAg sub-types in the Canadian blood-donor population. Rev Fr Transfus Immunohematol 1979;22:521-7.

9. Moore BPL. Incidence of hepatitis B antigen and antibody among Canadian volunteer blood donors. Can Med Assoc J 1972;107:396-9.

10. Guevin RM, Brown G, Talliano V. Donnees statistiques concemant l'antigene Australie pour la region ouest du Quebec. Union Med Can 1973;102:1260-3.

11. Sweet LE, Brown MG, Lee SH, Liston RM, MacDonald MA, Forward KR. Hepatitis B prenatal screening survey, Nova Scotia 1990-1991. Can J Public Health 1993;84:279-82.

12. Louie M, Low DE, Feinman SV, McLaughlin B, Simor AE. Prevalence of bloodborne infective agents among people admitted to a Canadian hospital. CMAJ 1992;146:1331-4.

13. Berris B, Feinman SV, Sinclair JC, Wrobel D. Hepatitis and hepatitis B surface antigen and antibody in dentists. Can Med Assoc J 1978;119:1040-3.

14. Richer G, Desrochers M, Guevin R, Turgeon F, Viallet A. Hepatitis B antigen in Montreal blood donors: childhood institutionalization as an epidemiologic factor. Can Med Assoc J 1975;112:49-52.

15. Richer G, Phaneuf D, Boisvert F, Guevin R, Viallet A. Differences in the distribution of e antigen among different ethnic groups in a population of blood donors. CMAJ 1977;116:757-9.

16. Kim Y-I, Heathcote J, Wanless IR. The hepatitis B carrier state - a follow-up study of 100 consecutive cases. Clin Invest Med 1987;10:383-7.

17. Bastiaans MJ, Nath N, Dodd RY, Barker LF. Hepatitisassociated markers in the American Red Cross volunteer blood donor population. IV. A comparison of HBV-associated serologic markers in HBsAg-positive first-time and repeat blood donors. Vox Sang 1982;42:203-10.

18. Villeneuve JP, Desrochers M, Infante-Rivard C, et al. A longterm follow-up study of asymptomatic hepatitis B surface antigen-positive carriers in Montreal. Gastroenterology 1994;106:1000-5.

19. Cheng HH, Wang DQ, Minuk GY, Anand CM, Stowe TC, Buchan KA. The prevalence of antibody to delta virus in western Canada. Clin Invest Med 1986;9:156-9.

20. Hannan C, Sekla L, Schacter B, Stackiw W. Antibody to hepatitis D virus (delta agent) in selected Manitoba residents, 1974-1986. Clin Invest Med 1988;11:209-12.

21. Feinman SV, Berris B, Cooter N, Sinclair JC, Wrobel DM. Results of long-term prospective study of the hepatitis $B$ surface antigen (HBsAg) carrier state. Hepatogastroenterology 1982;29:58-61.

22. McMahon BJ, Albert SR, Wainwright RB, Bulkow L, Lanier AP. Hepatitis B-related sequelae: prospective study in 1400 hepatitis B surface antigen-positive Alaska carriers. Arch Intern Med 1990;150:1051-554.

23. Beasley RP. Hepatitis B virus. The major etiology of hepatocellular carcinoma. Cancer 1988;61:1942-56.

24. Minuk GY, Ling N, Postl B, Waggoner JG, Nicolle LE, Hoofnagle $\mathrm{JH}$. The changing epidemiology of hepatitis B virus infection in the Canadian North. Am J Epidemiol 1985;121:598-604.

25. Philosophe B, Greig PD, Hemming AW, et al. Surgical management of hepatocellular carcinoma: resection or transplantation? J Gastrointest Surg 1998;2:21-7.

26. Hoofnagle J. Chronic type B hepatitis. Gastroenterology 1984;84:422-4.

27. Yuan L, Robinson G. Hepatitis B vaccination and screening for markers at a sexually transmitted disease clinic for men. Can J Public Health 1994;85:338-41.

28. Romanowski B, Campbell P. Sero-epidemiologic study to determine the prevalence and risk of hepatitis $B$ in Canadian heterosexual sexually transmitted disease population. Can J Public Health 1994;85:205-7.

29. Sellors J, Zimiv-Vincetic M, Howard M, Mahony JB, Chernesky MA. Predictors of positivity for hepatitis B and the derivations of a selective screening rule in a Canadian sexually transmitted disease clinic. J Clin Virol 1998;24:85-91.

30. Wang EE, King S, Goldberg E, Bock B, Milner R, Read S. Hepatitis $B$ and human immunodeficiency virus infection in street youths in Toronto, Canada. Pediatr Infect Dis J 1991;10:130-3.

31. Roy E, Haley N, Lemire N, Boivin J-F, Leclerc P, Vincelette J. Hepatitis B virus infection among street youths in Montreal. CMAJ 1999;161:689-93. 
32. Ellis CE, Erb LJ, McKeown DJ, McFarlane GM. Hepatitis B control in Toronto classrooms for the mentally retarded: a seroprevalence study. Can J Public Health 1990;81:156-60.

33. Statistics Canada 1996 Census. <www.statcan.ca/english/ Pgdb/people/population/demo39a.htm > (Version current at November 20, 2001)

34. Minuk GY, Nicolle LE, Postl B, Waggoner JG, Hoofnagle JH. Hepatitis virus infection in an isolated Canadian Inuit (Eskimo) population. J Med Virol 1982;10:255-64.

35. Minuk GY, Orr P, Jones S, Brown R, Macdonald S, Chaudhury RK. Chronic hepatitis B viral infections in the Canadian Inuit. A follow-up study. Proceedings of Tenth International Congress on Circumpolar Health. American Society of Circumpolar Health. Anchorage, May 9-13, 1996. (Abst 279)

36. Larke RPB, Froese GJ, Devine RDO, Petruk MW. Extension of the epidemiology of hepatitis B in circumpolar regions through a comprehensive serologic study in the Northwest Territories of Canada. J Med Virol 1987;22:269-76.

37. Baikie M, Ratnam S, Bryant DG, Jong M, Bokhout M Epidemiologic features of hepatitis B virus infection in Northern Labrador. CMAJ 1989;141:791-5.

38. Minuk GY, Yu D, Smith W, et al. Putrescine levels in the staple foods of the Canadian Inuit and Hong Kong Chinese: A possible explanation for discrepant hepatocellular carcinoma rates in the two populations. Arctic Med Res 1994;53:296-7.

39. Martin JD, Mathias RG. HIV and hepatitis B surveillance in First Nations alcohol and drug treatment centres in British Columbia, Canada. Int J Circumpolar Health 1998;57(Suppl 1):280-4.
40. Ratnam S, Head CB, Butler RW. Lack of evidence of hepatitis D (delta) infection in Newfoundland and Labrador. CMAJ 1986;134:905-7.

41. Minuk GY, Nicolle LE, Gauthier T, Brunka J. The prevalence of antibody to hepatitis $C$ virus in an isolated Canadian Inuit settlement. Can J Infect Dis 1991;2:71-3.

42. Storm HH, Nielsen NH. Cancer of the digestive system in Circumpolar Inuit. Acta Oncol 1996;35:553-70.

43. Chaudhary RK, Nicholls ES, Kennedy DA. Prevalence of hepatitis B markers in Indochinese refugees. Can Med Assoc J 1981;125:1243-6.

44. Nicholls ES, Chaudhary RK, Kennedy DA, Jung J, Davies JW, Gill P. Hepatitis B follow-up among Indochinese refugees. CMAJ 1984;131:1073-6.

45. Wong WWS, Minuk GY. A cross-sectional seroepidemiologic survey of chronic hepatitis B virus infections in Southeast Asian immigrants residing in Canadian urban centre. Clin Invest Med 1994;17:443-7.

46. Sherman M, Peltekian KM, Lee C. Screening for hepatocellular carcinoma in chronic carriers of hepatitis B virus: incidence and prevalence of hepatocellular carcinoma in a North American urban population. Hepatology 1995;22:432-8.

47. Canadian consensus conference on the management of viral hepatitis. Canadian Association for the Study of the Liver. Can J Gastroenterol 2000;14(Suppl B):5B-20B.

48. Hoofnagle JH. Therapy of viral hepatitis. Digestion 1998;59:563-78.

49. Dusheiko GM. Treatment and prevention of chronic viral hepatitis. Pharmacol Ther 1995;65:47-73.

50. Main J, McCarron B, Thomas HC. Treatment of chronic viral hepatitis. Antivir Chem Chemother 1998;9:449-60. 


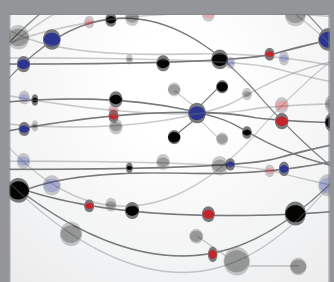

The Scientific World Journal
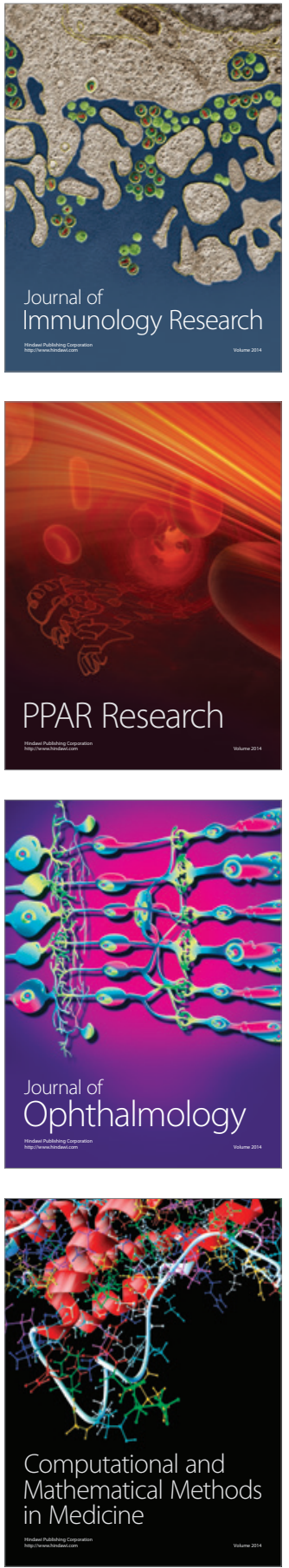

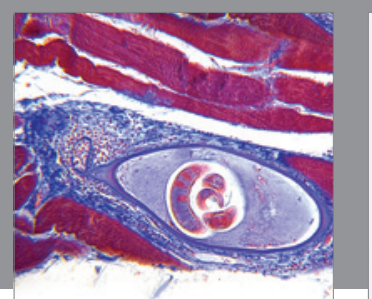

Gastroenterology Research and Practice

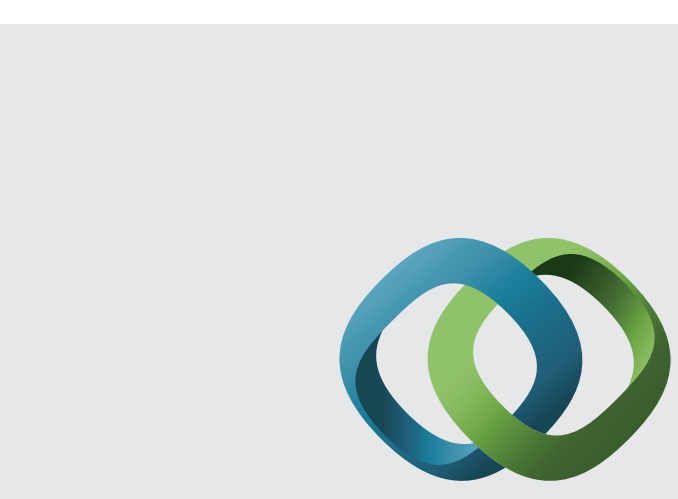

\section{Hindawi}

Submit your manuscripts at

http://www.hindawi.com
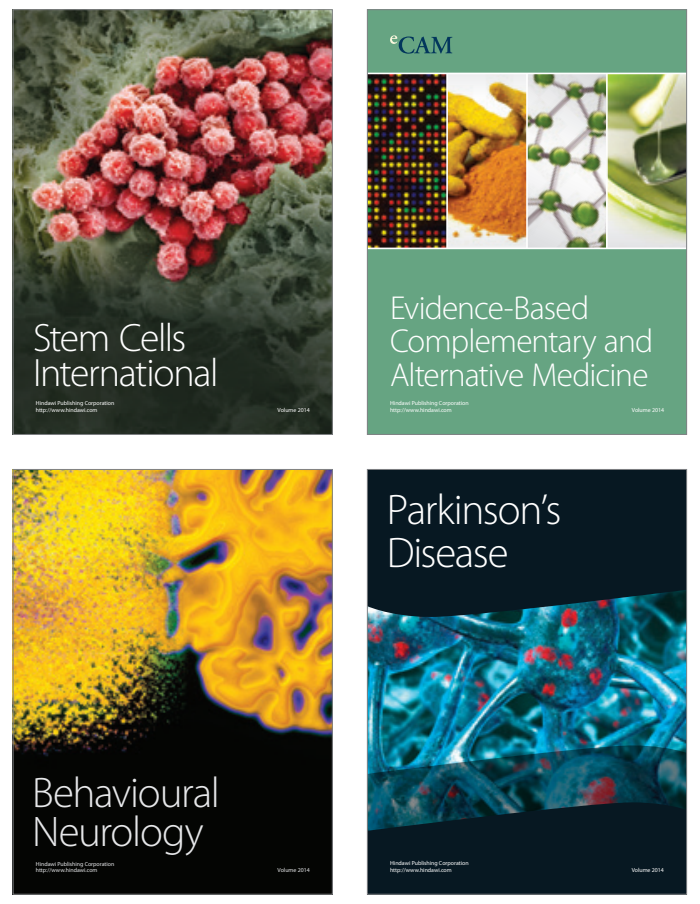
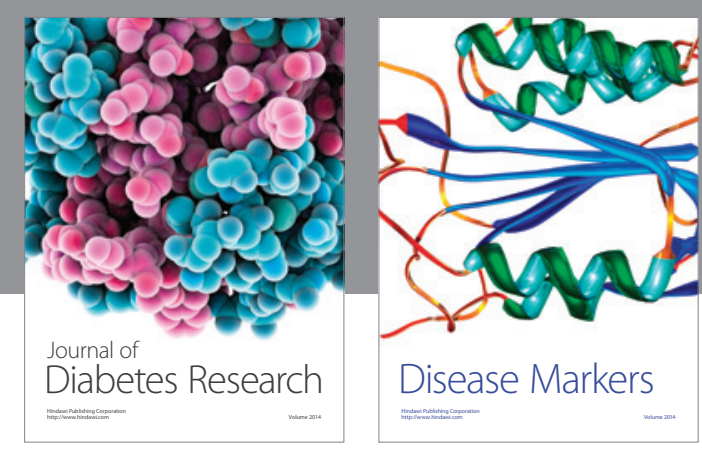

Disease Markers
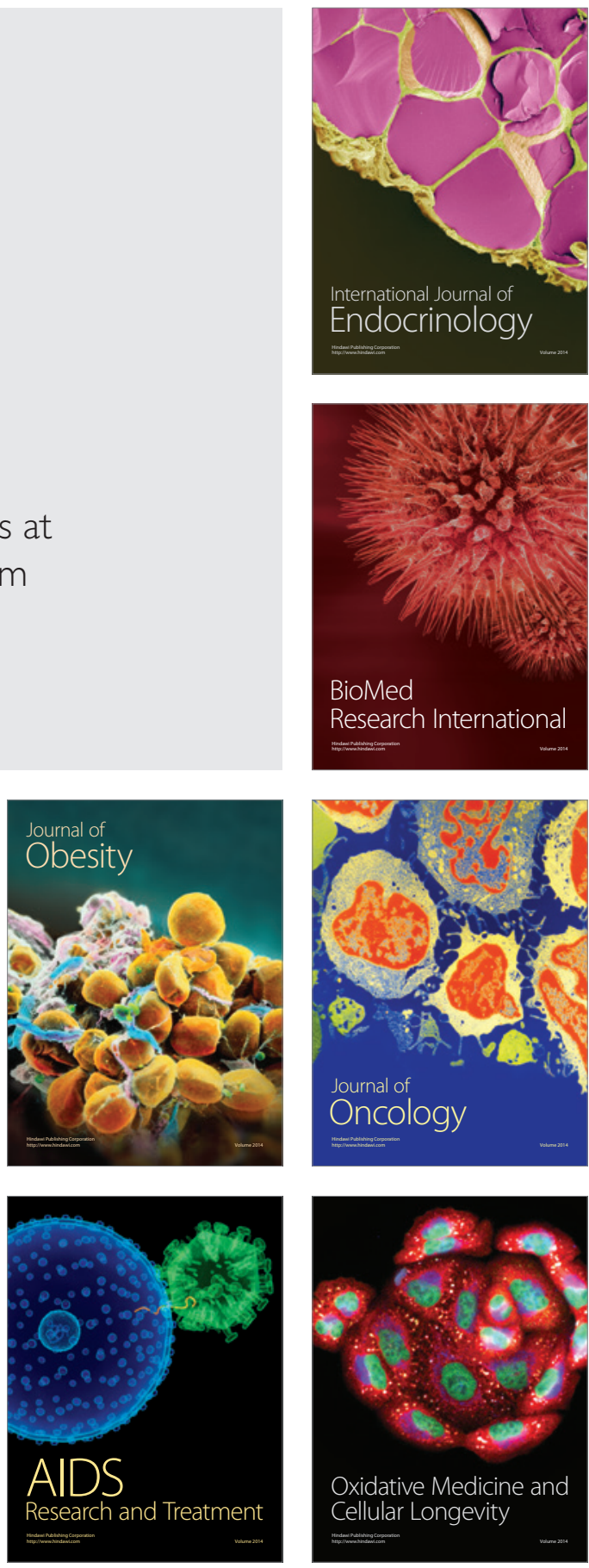